\title{
LINGUISTIC PRAGMATICS OF INTERCULTURAL PROFESSIONAL AND BUSINESS COMMUNICATION. ELENA N. MALYUGA \& SVETLANA N. ORLOVA. SPRINGER INTERNATIONAL PUBLISHING. 145 PP. ISBN 978-3-319-68744-5
}

\author{
А.А. Харьковская \\ aax2009@mail.ru \\ Ю.С. Старостина \\ juliatim@mail.ru
}

Самарский нащиональныий исследовательский университет им. С.П. Королева

(Самара, Россия)

Прежде, чем охарактеризовать представленную работу, необходимо сделать несколько предварительных замечаний о том тематическом контексте, в который она вписывается как заметное явление научного процесса в современной лингвистике.

В наши дни рынок книжной продукции, посвященной прикладным аспектам межкультурной коммуникации, регулярно пополняется изданиями зарубежных авторов, которые стремятся раскрыть теоретические основы и практические пути и способы обучения межкультурному взаимодействию на конкретных примерах и ситуациях, опираясь на весьма богатый опыт международного сотрудничества, где английский язык выполняет функции коммуникативного лидера в процессе реализации международных проектов. Научная и учебная литература по проблемам межкультурного

Elena N. Malyuga Svetlana N. Orlova

общения традиционно охватывает круг тем, связанных как с профессиональными, так и с бытовыми и общекультурными проблемами, в границах которых происходит овладение наиболее широко распространенными вербальными моделями эффективного речевого поведения не только носителей английского языка, но и других представителей международного сообщества, для которых английский язык является иностранным. Причем авторы зарубежных изданий активно дополняют свои материалы мастерски выполненными иллюстрациями и фотодокументами страноведческого характера, используя видеоролики и другие современные мультимедийные средства в попытке привлечь внимание к традиционным и современным ценностям британской или американской культур. Однако при всем разнообразии этих изданий их объединяет общая исходная установка, которой руководствуются зарубежные авторы, - активная пропаганда и безусловное доминирование образцов британских и американских моделей социокультурной адаптации; в то же время в подобных публикациях представленный материал нередко имеет ограниченную зону речевой коммуникации и 
весьма поверхностный уровень информационного содержания стереотипных коммуникативных ситуаций. В нашей стране всплеск популярности учебных и аналитических публикаций такого рода начался на рубеже восьмидесятых-девяностых годов XX века и с тех пор не утихает. В качестве примеров можно привести целый ряд авторитетных учебных изданий известных авторов:

- Dennis S. Gouran, William E. Wiethoff, Joel A. Doelger. Mastering Communication (Boston: Allyn and Bacon, 1994);

- Judy Irigoin, Bonnie Tsai, K. Baxendale. Business English Recipes: A Creative Approach to Business English (Pearson Education, 1995);

- Susan Norman, Eleanor Melville. We Mean Business (London: Addison-Wesley, 1997);

- Cristine Jonson. Intelligent Business (Pearson Education, 2005);

- серийные издания Language in Society, в частности Ronald Scollon and Susanne Wong Scollon. Intercultural Communication: A Discourse Approach (Blackwell Publishers, 1995).

Эти и другие подобные работы неоднократно переиздавались с учетом большого спроса на них во всем мире и масштабных рекламных кампаний. При этом многие специалисты (как и потребители данной продукции) признают, что наиболее удачны те из них, которые разработаны на основе системной репрезентации не только собственно языкового материала, но и теоретических наработок по проблематике межкультурного общения. Поэтому исследования по данной тематике никогда не теряют своей актуальности, тем более что в современном мире коммуникативное пространство меняется довольно быстро и постоянно порождает новые тенденции и объекты научного интереса для филологов.

Отечественные авторы рецензируемой монографии Linguistic Pragmatics of Intercultural Professional and Business Communication (рус.: Лингвистическая прагматика межкультурной профессиональной и деловой коммуникации) (издательство Springer, 2018) Е.Н. Малюга и С.Н. Орлова представляют Российский университет дружбы народов. Продолжая традиции прикладных исследований, опирающихся на серьезные теоретические посылы, они видят свою задачу в том, чтобы восполнить лакуну в изучении прагматически ориентированной межкультурной профессиональной и деловой коммуникации, таким образом создавая основу для разработки практических рекомендаций по подготовке представителей деловых кругов к эффективному взаимодействию с партнерами. Именно неразрывная связь теоретических и прикладных аспектов профессионального общения является базовой характеристикой данной работы, о чем можно судить по названию глав:

1. The Theory of Professional and Business Communication in Contemporary Linguistics.

2. Jargonisation, Manipulative Potential and Strategic Planning of Professional Discourse.

3. Theoretical Concepts and Notions of Euphemy.

4. Euphemisms in the Economic Discourse.

Авторы дают определение необходимых и достаточных признаков межкультурной профессиональной и деловой коммуникации (intercultural professional and business communication, или IPBC): "а complex process of the establishment, maintenance, and development of interpersonal contacts between people of different national identity in the professional sphere. This process takes place in the context of divergent national and cultural stereotypes of reflection and behaviour, as well as the regulations and standards recognised in the society, and emerges in the setting of business consensus established between the parties" (Malyuga \& Orlova 2018, p. 7).

Выдвигаются и анализируются следующие параметры этого типа общения: 
1. Наряду с определенной спецификой грамматической организации IPBC, более существенной еe характеристикой авторы считают своеобразие лексической подсистемы.

2. Обширное множество используемых в IPBC терминов включает как кодифицированные, так и некодифицированные единицы.

3. Употребление участниками общения многочисленных профессиональных жаргонизмов сигнализирует об их принадлежности к определенной профессиональной группе.

4. ІРВC присуще большое разнообразие эвфемизмов, наполняющих дискурс особыми смысловыми приращениями (Malyuga \& Orlova 2018, p. 26).

Справедливо выдвигая тезис о том, что познание особенностей межкультурной коммуникации, ее вариантов и изменений в условиях глобализации является одной из первоочередных задач современного языкознания, Е.Н. Малюга и С.Н. Орлова в рецензируемой монографии представляют результаты исследования, выполненного с позиций прагма-дискурсивного и, шире, функционального подхода к межкультурной профессиональной и деловой коммуникации. Авторы подробно анализируют лингвистические и экстралингвистические аспекты профессиональной коммуникации как в устной, так и в письменной форме. Наглядно иллюстрируется и тезис о том, что подобную коммуникацию можно считать эффективной только при условии, что ее участники знают и применяют ряд определенных неписаных норм и правил. При этом отмечается, что национальная идентичность говорящего и его культурные установки напрямую влияют на качество делового общения в межкультурном пространстве, правомерно предполагающем сотрудничество и взаимодействие.

В монографии детально показано, каким именно образом различные темы разговора (такие как экономические и социальные проблемы, образование и т. п.) влияют на лингвистическое наполнение профессиональной и деловой коммуникации. Всестороннее научное исследование, проведенное авторами на актуальном дискурсивном материале, доказывает, что успех изучаемого вида коммуникации зависит от целого ряда различных факторов, и уровень владения языком при этом - лишь один из них. Говорящий должен также следовать негласным правилам речевого этикета, адекватно использовать вербальные и невербальные средства коммуникации и демонстрировать полную осведомленность в регламенте мультикультурного и мультиязыкового коммуникативного пространства. Таким путем в большой степени обусловлена эффективность коммуникативного взаимодействия партнеров по общению, которые представляют различные национально-культурные социальные кластеры.

Избранный авторами надежный инструмент исследования в формате функционально-прагматического подхода позволил им проанализировать многочисленные аспекты речевого поведения представителей различных культур и представить достоверные и устойчивые эмпирические данные в сопровождении теоретических интерпретационных комментариев. В монографии затрагиваются как вопросы, касающиеся проблем речевого воздействия на адресата, так и вопросы стратегического планирования речевого поведения, что отвечает вызовам современной межкультурной коммуникативной парадигмы.

В ходе проведенного исследования авторы применяют актуальные методы лингвистического анализа, а именно когнитивно-дискурсивный анализ, полифакторный анализ лексических единиц, текстуальный анализ, сопоставительный анализ и т. д. В центре внимания исследователей находятся ключевые лингвистические характеристики профессиональной и деловой коммуникации: эвфемизация речи, генерализация и консолидация профессиональной терминологии, кодификация лексики. Научный анализ проводится с привлечением мультиязыковых эмпирических данных, а именно, текстов, 
написанных на английском, французском и итальянском языках, и соответственно, отражает особенности этих языков и специфику их актуализации в контексте деловой профессиональной коммуникации.

Цель, сформулированная авторами рецензируемой монографии, заключается в идентификации и систематизации основных лингвопрагматических особенностей межкультурной профессиональной и деловой коммуникации, выделении эвфемизмов по экономической тематике и изучении способов их реализации в профессиональном деловом дискурсе с учетом как лингвистических, так и экстралингвистических параметров коммуникации. Цель полностью достигнута авторами путем поэтапного решения исследовательских задач, подробно представленных во введении и затем последовательно раскрываемых в четырех главах работы в ракурсе функциональностилистического подхода к интерпретации ключевых лингвокультурных и лингвопрагматических маркеров стратегической и тактической организации межкультурного делового и профессионального дискурса на материале указанных выше европейских языков.

В связи с этим особый интерес представляет лингвопрагматическое описание последствий лингвистической глобализации и процессов интернационализации в контексте Европейского лингвистического ареала, раскрытие манипулятивного потенциала стереотипного речевого поведения, свойственного носителям европейских языков, в сочетании с ведущими лексическими и стилистическими параметрами профессиональной и деловой коммуникации на современном этапе развития европейского социума. Несомненно, положительной оценки заслуживают выводы авторов монографии относительно особенностей сочетания эвфемизации/дисфемизации с ироническим вкраплениями в контекст экономического дискурса, с одной стороны, и авторские комментарии по поводу использования стилистически маркированной лексики (жаргонизмов, профессионализмов и т.п.) в масс-медийных публикациях на экономическую тему, - с другой; именно эти явления обеспечивают деловое профессиональное общение «жизненными силами», расширяя его границы до неформального разговорного жанра, что может повысить его эффективность. Привлечение сведений из области междисциплинарных разработок по проблемам социолингвистики, психолингвистики, философии языка и дискурс-анализа способствует уточнению межкультурных кодовых сигналов и достоверной расшифровке прямых и опосредованных способов формирования общественного мнения в сфере экономических преобразований, продиктованных требованиями эпохи глобализации.

Достоинством рецензируемой монографии также является значительное расширение общей парадигмы лингвистического поля межкультурной коммуникации. В работе наряду с систематизацией языковых маркеров профессиональной и деловой коммуникации проведена их концептуальная генерализация, определены ключевые характеристики межкультурной коммуникации с привлечением убедительных лингвистических иллюстраций, проанализирован функционально-прагматический аспект данной коммуникации с учетом современных данных лингвокогнитивистики, а также предложена авторская интерпретация лингвистических и прагматических параметров функционирования английского профессионального жаргона в нескольких европейских языках.

Следует подчеркнуть, что в результате предпринятого авторами исследования сформулированы концептуально значимые выводы по поводу социальноэкономических факторов в конкретной стране, уровень концентрации которых предопределяет особенности использования эвфемизмов в международной деловой коммуникации: носители итальянского и французского языков используют 
англоязычные эвфемизмы-заимствования для смягчения или сокрытия истинного значения высказывания. Для таких эвфемизмов характерна широкая референтность при неоднозначном уровне экспрессивности.

Полученные авторами результаты анализа могут быть экстраполированы на решение практических задач при обучении деловой и профессиональной коммуникации, при составлении аналитических обзоров по экономической проблематике в условиях реализации межкультурных проектов в международных масштабах, при написании отчетов и научных докладов, а также в ходе дальнейших научных изысканий в области иноязычной профессиональной коммуникации.

В качестве возможных перспектив развития этапов лингвопрагматического совершенствования профессиональной коммуникации в части реализации проектов межкультурного сотрудничества можно порекомендовать Е.Н. Малюге и С.Н. Орловой продолжить работу по сбору и систематизации информации о специфике межкультурной коммуникации с партнерами по экономическому деловому общению из Восточного ареала, где коммуникативная парадигма значительно отличается в плане маркирования национально-культурных особенностей речевого поведения. 